\title{
Analysing User Experience of Mobile Banking Applications in Nigeria: A Text Mining Approach
}

\author{
Babatunde S. Omotosho ${ }^{1}$
}

This paper analyses textual data mined from 37,460 reviews written by mobile banking application users in Nigeria over the period November 2012 - July 2020. On a scale of 1 to 5 (5 being the best), the average user rating for the twenty-two apps included in our sample is 3.5; with the apps deployed by non-interest banks having the highest average rating of 4.0 and those by commercial banks with national authorisation having the least rating of 3.4. Results from the sentiment analysis reveal that the share of positive sentiment words (17.8\%) in the corpus more than double that of negative sentiment words (7.7\%). Furthermore, we find that about 66 per cent of the emotions expressed by the users are associated with 'trust', 'anticipation', and 'joy' while the remaining 34 per cent relate to 'surprise', 'fear', 'anger', and 'disgust'. These results imply that majority of the users are satisfied with their mobile banking experience. Finally, we find that the main topics contained in the user reviews pertain to (i) feedback on banks' responsiveness to user complaints (ii) user experience regarding app functionalities and updates, and (iii) operational failures associated with the use of the apps. These results highlight the need for banks to continue to promote awareness of existing functionalities on their apps, educate users on how those solutions could be accessed, and respond to user feedback in a timely and effective manner.

Keywords: Mobile banking, sentiment analysis, text mining JEL classification: C46, C55, D14, D18, E44, E58, G20

DOI: $10.33429 / C$ jas. $12121.4 / 6$

\subsection{Introduction}

The deployment of mobile banking and payments applications has recorded tremendous growth over the years. This is due to several reasons, including increased mobile phone penetration; financial inclusion efforts of governments; and the demand for more efficient means of payments by financial market participants (Patnam \&

\footnotetext{
${ }^{1}$ The author is staff of the Statistics Department, Central Bank of Nigeria. The views expressed in this paper are those of the author and do not in any way represent the position of the Central Bank of Nigeria.
} 
Analysing User Experience of Mobile Banking Applications in Nigeria:

A Text Mining Approach

Omotosho

Yao, 2020; Aron, 2018; Mbiti \& Weil, 2015). Also, the limited availability of physical infrastructure for effective conventional banking activities provides an impetus for rapid adoption of digital financial services in developing countries. According to Global System for Mobile Communication Association (GSMA, 2019), the total number of mobile money accounts registered worldwide increased to about 1.0 billion in 2019 from 29.3 million a decade earlier, with sub-Saharan Africa accounting for about half of the registrations. In 2019, the value of daily transactions via mobile accounts stood at about US $\$ 2$ billion, as households and firms relied predominantly on digital payments for transactions relating to school fees, e-commerce, international remittances, savings, credit, pay-as-you-go utilities, among others (GSMA, 2019). According to Total System Services (TSYS, 2018), many bank customers also use mobile banking app for non-transactional purposes, such as checking account balance and viewing recent transactions.

Mobile payments refer to the category of financial transactions conducted using access devices that are enabled by mobile communication networks (Committee on Payment and Settlement Systems [CPSS], 2012). These transactions are often initiated and transmitted over mobile communication protocols like Short Message Services, mobile applications, web browsers for mobile phones, Near Field Communications, and Quick Response Codes (Khiaonarong, 2014). The funds utilised under mobile payment arrangements are sourced from linked accounts, which may either be (i) customer funded bank accounts, or (ii) customer stored-value funds maintained by mobile network operators (CPSS, 2012). Thus, the ecosystem for digital financial services is managed by a number of critical stakeholders including: banks; telecommunication companies; and third party software companies (Castle et al., 2016).

In Nigeria, the size of mobile payments has risen dramatically over the last few years in response to global, domestic, market, technological, and regulatory factors. Data from the Nigeria Interbank Settlement System (NIBSS) show that while the volume of mobile transactions was 51 million in 2017, it reached 410 million in 2019 representing a growth of about 703.9 per cent (see Figure 1a). Similarly, the value of mobile transactions increased sharply from N196.3 billion in 2017 to N828.1 billion in 2019. The value of mobile transactions (N853.7 billion) recorded in the first five 
months of 2020 surpassed the total amount recorded in 2019 by 3.1 per cent. The phenomenal growth in the value of mobile payments, especially in May 2020 (Figure 1b) can be partly explained by the effects of the restricted human movements associated with the lockdown measures implemented in response to the Covid-19 pandemic.

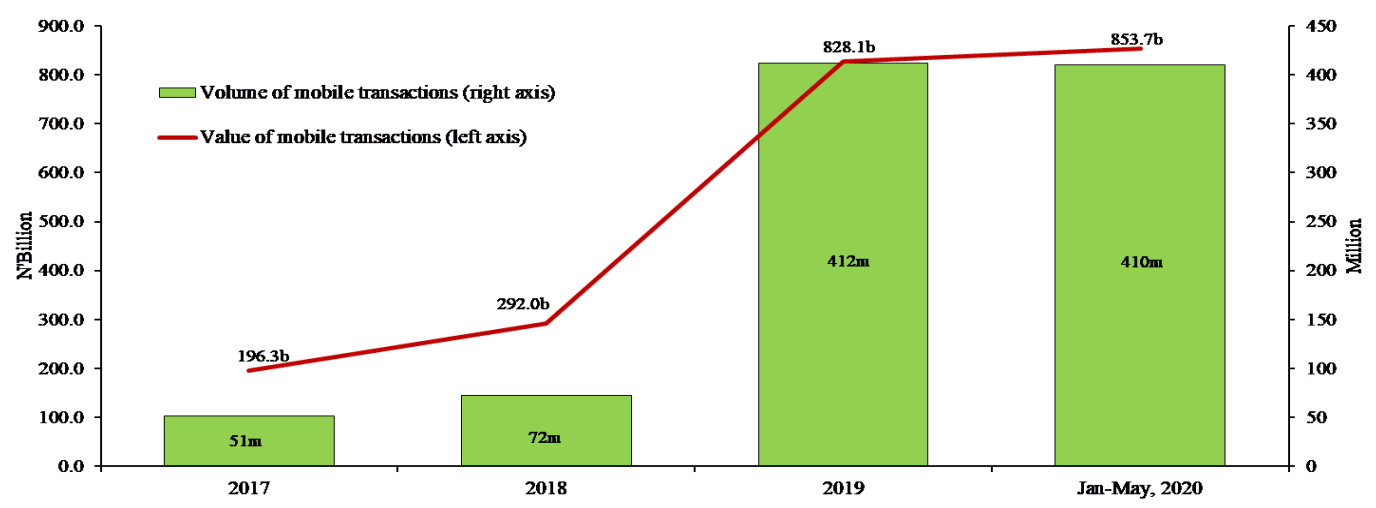

Figure 1a: Annual volume and value of mobile transactions, 2017-2020.

Source: Nigeria Inter-Bank Settlement System Plc.

The increasing relevance of mobile payments as a share of global financial transactions presents financial authorities with the added responsibility of ensuring consumer protection as well as payment system efficiency and safety on such platforms. Khiaonarong (2014) provides a detailed account of relevant legal and regulatory interventions that have been implemented in different countries, including explicit mobile payment regulations. Examples of such regulations are the Da Afghanistan Bank Money Service Providers Regulation of 2008; the Reserve Bank of India's Operative Guidelines for Mobile Banking Transactions of 2011; the Bank of Uganda's Mobile Money Guidelines of 2013; the Central Bank of Brazil's Law 12865 of 2013; and the Central Bank of Nigeria's Guidelines on Mobile Money Services of 2015 as well as the associated regulatory framework.

The literature on mobile money services is still at its infancy, with the existing studies focusing on regulatory oversight and security issues in mobile banking and payments (Khiaonarong, 2014; Reaves et al., 2017); the economic impacts of mobile money services (Patnam \& Yao, 2020; Wieser et al., 2019); determinants of mobile banking 
Analysing User Experience of Mobile Banking Applications in Nigeria:

A Text Mining Approach

Omotosho

adoption (Khan \& Ejike , 2017; Agwu \& Carter, 2014); and the analysis of user experience (Olaleye et al., 2017). Of these, an area that has received little attention in literature relates to the analysis of feedback provided by bank customers on their experiences with digital financial applications. This area of research is important for a number of reasons. First, it helps to draw the attention of mobile banking and payments apps providers to operational issues being faced by their customers and users. Second, it helps banks gauge the extent to which customers are adopting their services. Third, it helps financial regulators detect factors that could potentially threaten payments and financial system stability and financial inclusion efforts.

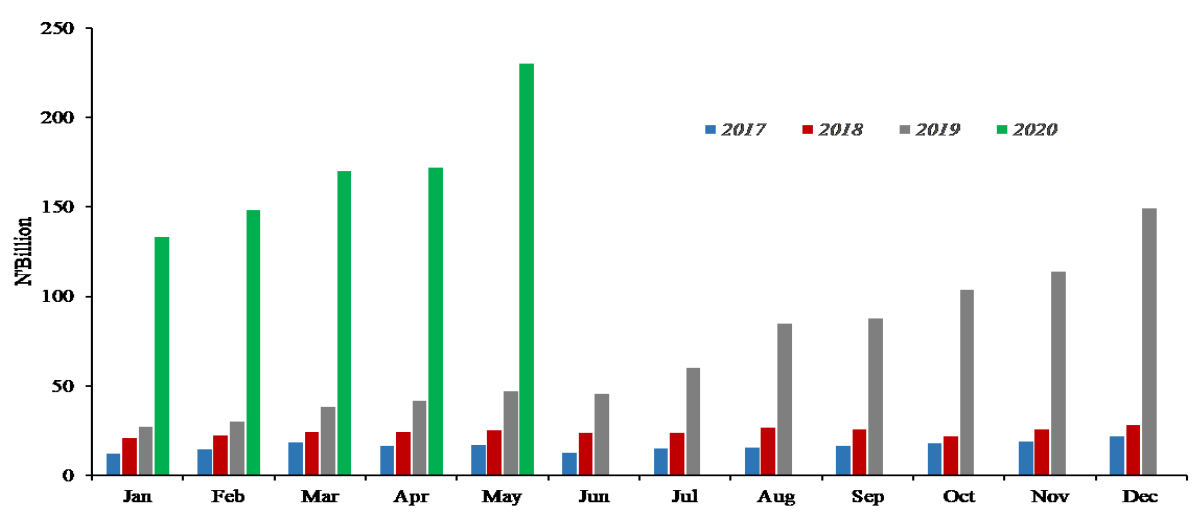

Figure 1b: Monthly value of mobile transactions, January 2017 - May 2020.

Source: Nigeria Inter-Bank Settlement System Plc

This study analyses the experiences of users of mobile banking applications in Nigeria. In contrast to existing studies on Nigeria that are based on the analysis of survey returns, this study applies text mining techniques to textual data mined from the reviews written by mobile banking application users. The study finds this approach appealing for several reasons. First, it allows for the use of information from a wider spectrum of mobile banking apps users in a less costly manner. Second, compared to returns from structured questionnaires, it allows for the analysis of a wider range of issues as all the issues raised by users in their reviews are considered. Third, it allows us to detect the key topics, sentiments, and emotions expressed in the user reviews. In addition, the hidden topics in the reviews are identified using the Latent Dirichlet Allocation (LDA) modelling approach. To our knowledge, this study represents the 
first attempt in this direction for Nigeria. This effort is in line with the G20 principles for innovative financial inclusion, which support the creation of knowledge to enhance the versatility of digital financial services provisioning (Access through Innovation Sub-Group, 2010).

The rest of the paper is laid out as follows: Section 2 provides a review of related literature. Section 3 describes the text mining procedures used for the analysis. In Section 4, the results are presented and discussed. Section 5 provides some concluding remarks and policy recommendations.

\subsection{Literature Review}

The literature on mobile money services can be categorised under four major strands (Appendix 1). The first strand relates to regulatory oversight and security issues in mobile banking and payments (Contini et al., 2011; Chatain et al., 2011; Khiaonarong, 2014; Castle et al., 2016; Reaves et al., 2017). For instance, Khiaonarong (2014) argued that countries with relatively high deployments of mobile payments would benefit from the implementation of oversight measures aimed at ensuring that such digital invention does not disrupt payment and financial system stability. It is argued that, among others, financial authorities can preserve public confidence in mobile payments and enhance financial stability by implementing oversight measures such as: an explicit legal regime; anti-money laundering and countering the financing of terrorism measures for preventing financial integrity risks without stifling innovation; fund protection measures such as pass through deposit insurance; contingency plans for operational disruptions; and risk controls in payment systems. According to Dittus and Klein (2011), regulatory frameworks should be designed to help achieve financial inclusion and in a manner that they can be easily amended should the growth in mobile payments becomes rapid enough to threaten financial stability. Also crucial for successful mobile banking and payments is the need for effective coordination between bank and non-bank regulators (Contini et al., 2011).

The second strand focuses on the economic impacts of mobile money. Some of the economic benefits identified in the literature include increased banks' profitability (Okon \& Amaegberi, 2018), higher customer satisfaction (Adewoye, 2013), en- 
Analysing User Experience of Mobile Banking Applications in Nigeria:

A Text Mining Approach

Omotosho

hanced financial inclusion and stability (Mbiti \& Weil, 2015; Ozili, 2018; Aron, 2018; Bongomin et al., 2018), reduction in cost of remittance transactions (Mbiti \& Weil, 2015; Aron, 2018; Wieser et al., 2019), increased banking system efficiency (Mbiti \& Weil, 2015), improved resilience of households to shocks (Patnam $\&$ Yao, 2020), increased household and firm's savings (Jack \& Suri, 2011; Mbiti \& Weil, 2015; Aggarwal et al., 2020), enhanced self-employment (Mbiti \& Weil, 2015; Wieser et al., 2019), trade facilitation (Jack \& Suri, 2011), higher firms' sales (Patnam \& Yao, 2020), reduction in food insecurity (Wieser et al., 2019), promotion of informal risk sharing (Jack \& Suri, 2011), and improved livelihoods especially in developing countries (Wieser et al., 2019).

The third strand of the literature studies the determinants of mobile banking adoption (see Bankole et al., 2011; Odumeru, 2013; Agwu \& Carter, 2014; Ifeonu \& Ward, 2015; Khan \& Ejike, 2017). These studies, which are largely based on survey of mobile banking and payment users identify factors such as literacy level, versatility of the mobile banking system, convenience of use, culture, security, cost of transaction compared to other alternatives, complexity of the system, compatibility with the circumstances of the user, and the visibility of its benefits to users.

An area that has received little or no attention in literature relates to the analysis of feedbacks provided by bank customers on their experiences using digital financial applications. A few studies have been conducted on the adoption of mobile banking technology in Nigeria with most of them based on the administration of structured questionnaire to a limited number of respondents. For instance, Olaleye et al. (2017) analysed the experience of mobile money users in Nigeria using a survey of 151 respondents. It was shown that features such as security, privacy and convenience make mobile money attractive to users. Also, based on a survey of 1,725 respondents, Ifeonu and Ward (2015) found that mobile technology trust and adoption behaviour in Nigeria are driven by factors that include confidentiality, integrity, authentication, and access control. In addition to these, Odumeru (2013) conducted a survey covering 91 users of mobile banking in Nigeria and found that the complexity of the system as well as compatibility of the system with the circumstances of the user matter for mobile banking adoption. This paper relates to the literature strand 
analysing the experiences of mobile banking and payments apps users.

\subsection{Data and Methodology}

Following the definition of Barnes and Corbitt (2003) the mobile banking apps considered in this paper are those deployed by financial services providers for the purposes of offering certain transactional and non-transactional financial services to customers with bank accounts ${ }^{2}$. Once the app is downloaded and the sign-up as well as sign-in procedures are successfully completed, the user is granted access to their bank accounts for the purpose of conducting mobile banking activities that are permitted by the bank. In addition, the apps allow users to write reviews about their mobile banking experience and also provide quantitative ratings of the bank's performance. Such feedback constitutes an important source of information for both the app providers (the banks) and the regulatory authority.

The textual data analysed in this study comprises of reviews provided by users of mobile banking apps developed by 22 Nigerian banks. The analyses are implemented using the $R$ statistical software. The downloaded reviews cover all iOS and Android mobile banking apps available on Google Play and App Store via Heedzy. In all, we downloaded a total of 37, 460 reviews spanning the period, November 2012 July 2020, representing all the reviews available with Heedzy for the selected apps (Table 1). ${ }^{3}$ Of these, a total of 23, 308 (representing about 62 per cent) pertain to mobile banking apps deployed by commercial banks with international authorisation (CBIA) while 13, 772 reviews pertain to apps deployed by banks with national authorisation. The remaining reviews were accounted for by commercial banks with regional authorisation (109 reviews) and non-interest banks (271 reviews).

\footnotetext{
${ }^{2}$ In the case of mobile payments, the user is not required to hold an account with a bank.

${ }^{3}$ This paper has a number of weaknesses. First, being the first attempt at analysing user reviews on mobile banking apps for Nigeria, we opted to cover all the textual data available on Heedzy.com; rather than limiting the sample to a period that is uniform across the banks. Thus, this approach reduces the ability of the paper to study the evolution of user sentiments overtime. Second, the long historical data considered in the paper for some of the banks implies that some of the concerns contained in the analysed reviews may have been overtaken by technological advancements. However, for upgrades to mobile apps that are successful in addressing certain legacy concerns, the positive sentiments associated with such improvements would have been captured in our paper.
} 
Analysing User Experience of Mobile Banking Applications in Nigeria: A Text Mining Approach

Omotosho

Table 1: Distribution of downloaded reviews

\begin{tabular}{|c|c|c|c|}
\hline Bank authorisation & $\begin{array}{l}\text { Mobile applica- } \\
\text { tion }\end{array}$ & Period & No. of reviews \\
\hline \multirow{10}{*}{$\begin{array}{l}\text { Commercial Banks with } \\
\text { International Authorisation } \\
\text { (CBIA) }\end{array}$} & Access Bank & July 2014 - July 2020 & 3,108 \\
\hline & FCMB & March 2015 - July 2020 & 1,585 \\
\hline & Fidelity Bank & October 2015 - July 2020 & 2,526 \\
\hline & First Bank & October 2015 - July 2020 & 3,291 \\
\hline & Guaranty Trust & November 2012 - July 2020 & 3,434 \\
\hline & Bank & & \\
\hline & Union Bank & January 2018 - July 2020 & 3,016 \\
\hline & $\begin{array}{l}\text { United Bank for } \\
\text { Africa }\end{array}$ & August 2015 - July 2020 & 3,207 \\
\hline & Zenith Bank & November 2013 - July 2020 & 3,141 \\
\hline & Sub-total & & 23,308 \\
\hline \multirow{10}{*}{$\begin{array}{l}\text { Commercial Banks with } \\
\text { National Authorisation } \\
\text { (CBNA) }\end{array}$} & Ecobank & July 2016 - July 2020 & 3,117 \\
\hline & Heritage bank & January 2016 - July 2020 & 471 \\
\hline & Keystone Bank & January 2018 - July 2020 & 1,077 \\
\hline & Polaris Bank & August 2019 - July 2020 & 915 \\
\hline & Stanbic IBTC & November 2016 - July 2020 & 2,739 \\
\hline & $\begin{array}{l}\text { Standard Char- } \\
\text { tered }\end{array}$ & June 2013 - July 2020 & 1,753 \\
\hline & Sterling Bank & May 2018 - July 2020 & 3,000 \\
\hline & Titan Trust Bank & November 2019 - July 2020 & 37 \\
\hline & Unity Bank & November 2013 - July 2020 & 663 \\
\hline & Sub-total & & 13,772 \\
\hline \multirow{4}{*}{$\begin{array}{l}\text { Commercial Banks with } \\
\text { Regional Authorisation } \\
\text { (CBRA) }\end{array}$} & Globus Bank & November 2019 - July 2020 & 45 \\
\hline & Providus Bank & April 2019 - July 2020 & 43 \\
\hline & Suntrust Bank & September 2019 - July 2020 & 21 \\
\hline & Sub-total & & 109 \\
\hline \multirow[t]{3}{*}{ Non-Interest Banks (NIB) } & Jaiz Bank & June 2015 - July 2020 & 230 \\
\hline & Taj Bank & November 2019 - July 2020 & 41 \\
\hline & Sub-total & & 271 \\
\hline Grand total & & & 37,460 \\
\hline
\end{tabular}

Source: Compiled by the author from Heedzy.com

Following data collection, our corpus, which is a collection of the entire reviews, is subjected to a number of pre-processing steps in line with standard text mining proce- 
dures. First, we remove numbers, punctuations, white spaces, and special characters from the corpus. Second, the characters in the corpus are converted to lower case while English stop words such as 'to', 'the', 'this', 'in' are removed. The tm map function of the $t m$ package developed by Feinerer and Meyer (2008) is used for the data cleaning and transformation. Other common informal Nigerian terms such as 'choi', 'buh', and 'chai' are removed. In addition, a number of informal spelling of words such as 'tanx', 'fyn', '9ice', 'kul' as well as contextual inconsistencies in the written reviews are corrected manually. Lastly, to ensure the terms in the corpus are uniquely identified, we stem the words in the document using the stemDocument argument of the tm map function.

Word clouds are used to identify common terms in the corpus while analyses of sentiments and emotions are conducted to derive useful insights regarding the type of feelings and experiences that are predominant in the corpus. The sentiment analysis is implemented based on Rsentiment; an R statistical package developed to analyse the sentiments contained in a sentence (Bose et al., 2017). Particularly, we apply the calculate sentiment function to classify the words contained in our corpus to three categories - positive, neutral, and negative. The share of each category in the total number of words in the corpus is then computed to gauge the level of positivity or negativity in the reviews. It is important to note that the calculate sentiment function is a unigram, rule-based approach to sentiment analysis that classifies texts in a binary sense. In other words, it uses the bag-of-words approach and calculates the sentiment score by matching the appearances of words in the textual data with pre-existing lexicons. An alternative to this approach is the use of automatic classifiers, which employ classification algorithms that are either probabilistic or non-probabilistic. We adopt the rule-based approach in this paper for its simplicity and the fact that the goal is not to develop a predictive model for classifying incoming user reviews. The study also explores the emotions expressed in the reviews using the Syuzhet package. This procedure classifies the emotions present in a corpus into eight categories based on the Canadian National Research Council (NRC) sentiment dictionary and computes their respective valence (Mohammad \& Turney, 2010). These are emotions relating to 'anger', 'anticipation', 'disgust', 'fear', 'joy', 'sadness', 'surprise', and 'trust'. 
Analysing User Experience of Mobile Banking Applications in Nigeria:

A Text Mining Approach

Omotosho

Furthermore, we compute the polarity score, which is a quantitative measure of positive or negative intent found in the tone of the reviews (Kwartler, 2017). The polarity function in the qdap library is employed for this purpose. The average polarity score ranges between -1 and 1; where a negative value indicates negative sentiment, a value of zero indicates neutral sentiment, and a positive value connotes positive sentiment. The analyses of sentiments are conducted for four categories of banks operating in the country and the results are benchmarked against the outturn for the entire sample. The bank categories are as follows: commercial banks with international authorisation (CBIA), commercial banks with national authorisation (CBNA), commercial banks with regional authorisation (CBRA), and non-interest banks (NIB).

Finally, this study analyses the hidden sub-themes in our corpus based on the Latent Dirichlet Allocation (LDA) modelling approach of Blei et al. (2003). The LDA is chosen for a number of reasons. First, the topics produced under the LDA is probabilistic, compared to non-probabilistic topics generated under methods such as the Latent Semantic Analysis of Deerwester et al. (1990). Second, it has been shown that the LDA yields superior outcomes in terms of generating semantically meaningful topics as well as assigning texts to the identified topics (Debortoli et al., 2016; Chang et al., 2009). Third, it has been used extensively in different applications, including Tumala and Omotosho (2019) for monetary policy communication in Nigeria; Omotosho (2020) for monetary policy communication in Ghana; and Hansen et al. (2018) for monetary policy communication in the US. More importantly, the LDA allows not only for identifying the hidden topics, but also to estimate the degree to which each topic is reflected in the corpus.

The LDA is a generative probabilistic process that is based on the assumption that each document consists of a mixture of topics, and each topic is a distribution over a given number of words (Shirota et al., 2015). Following the works of CalvoGonzález et al. (2018); Shirota et al. (2015); Blei and Lafferty (2009); and the definitions in Blei et al. (2003), a word is defined as an item in a vocabulary indexed by $\{1, \ldots \ldots, V\}$. Also, a document $\mathbf{w}$ is given by an array of $N$ words such that $\mathrm{w}=\left(w_{1}, \ldots, w_{N}\right)$ while a corpus represents a collection of $M$ documents such that $D=\left(\mathrm{w}_{1}, \ldots, \mathrm{w}_{M}\right)$. 
For each document $\mathbf{w}$, the generative process assumed by the LDA proceeds in the following steps:

Step 1: Choose $N \sim$ Poisson $(\varepsilon)$

Step 2: Choose $\theta \sim \operatorname{Dir}(\alpha)$

Step 3: For each word $w_{n}$, draw a topic assignment $z_{n} \sim \operatorname{Multinomial}(\theta)$ and also choose a word $w_{n}$ from a multinomial probability conditioned on the topic $z_{n}$ given by $p\left(w_{n} \mid z_{n}, \beta\right)$. $\beta$ represents the parameter of the Dirichlet prior on the per-topic word distribution while $\alpha$ is the parameter of the Dirichlet prior on the per-document topic distribution. For the given parameters $\alpha$ and $\beta$, the joint distribution of $\theta, z$ and $\mathrm{w}$ is as follows:

$$
p(\theta, z, \mathrm{w} \mid \alpha, \beta)=p(\theta \mid \alpha) \prod_{n=1}^{N} p\left(z_{n} \mid \theta\right) p\left(w_{n} \mid z_{n}, \beta\right) .
$$

The marginal distribution of a document is obtained by integrating over $\theta$ and summing over $z$ as follows:

$$
p(\mathrm{w} \mid \alpha, \beta)=\int p(\theta \mid \alpha)\left(\prod_{n=1}^{N} \sum_{z_{n}} p\left(z_{n} \mid \theta\right) p\left(w_{n} \mid z_{n}, \beta\right)\right) d \theta
$$

while the probability of a corpus is derived by taking the product of the marginal probabilities of the single documents as follows:

$$
p(D \mid \alpha, \beta)=\prod_{d=1}^{M} \int p\left(\theta_{d} \mid \alpha\right)\left(\prod_{n=1}^{N_{d}} \sum_{z_{d n}} p\left(z_{d n} \mid \theta_{d}\right) p\left(w_{d n} \mid z_{d n}, \beta\right)\right) d \theta_{d}
$$

Given a document and the Dirichlet priors, the LDA computes the posterior distribution of the hidden variables as follows:

$$
p(\theta, z \mid \mathrm{w}, \alpha, \beta)=\frac{p(\theta, z, \mathrm{w} \mid \alpha, \beta)}{p(\mathrm{w} \mid \alpha, \beta)}
$$

Thus, we are able to find the distribution of words over each topic as well as the mixture of topics driving each document. Since calculating the maximum likelihood for equation (4) is computationally costly and sometimes intractable, it is often approximated using the Collapsed Gibbs sampling algorithm (Calvo-González et al., 2018). 
Analysing User Experience of Mobile Banking Applications in Nigeria:

A Text Mining Approach

Omotosho

This paper employs the $l d a$ package (Chang \& Dai, 2015), which implements the LDA using the collapsed Gibbs sampling methods to model the topics in the corpus.

\subsection{Results and Discussion}

In this section, we present the results relating to the analyses of the quantitative ratings as well as the qualitative comments provided by bank customers while using their mobile banking apps. The ratings are analysed using averages and percentage shares while text mining techniques are applied to the qualitative comments. Generally, we consider results for the full sample, which comprises reviews on apps deployed by 22 commercial banks operating in Nigeria. The list of banks in our sample with their authorisation category is provided in Table 1.

\subsection{Analysis of User Ratings}

Table 2 presents the average rating assigned by users, with the rating ranked from 1 to 5 . The value 1 represents the least rating while the best rating is ranked 5 . The average user rating for the 37, 460 reviews analysed over the period December 2012 - July 2020 is about 3.54. This tends to suggest that most users were relatively satisfied with their mobile banking apps. Furthermore, the average user rating for the different categories of banks operating in the country is computed. At average values of about 3.6 and 4.0, the results for commercial banks with international authorisation (CBIA) and non-interest banks (NIB) show ratings that are above the average for the full sample. On the other hand, commercial banks with national and regional authorisations show ratings that are below the average.

Table 2: Average user rating by bank authorisation category

\begin{tabular}{lll}
\hline Bank authorisation & $\begin{array}{l}\text { No. of reviews } \\
\text { analysed }\end{array}$ & $\begin{array}{l}\text { Average user } \\
\text { rating }\end{array}$ \\
\hline Commercial Banks with International Authorisation (CBIA) & 23,308 & 3.6038 \\
Commercial Banks with National Authorisation (CBNA) & 13,772 & 3.4154 \\
Commercial Banks with Regional Authorisation (CBRA) & 109 & 3.4678 \\
Non-Interest Banks (NIB) & 271 & 4.0000 \\
\hline Total & 37,460 & 3.5370 \\
\hline
\end{tabular}

Figure 2 shows the distribution of the sample across the different user ratings. Of the 37, 460 mobile app users, about 51 per cent gave the best rating of 5 while about 
27 per cent assigned the least rating of 1 . Overall, about 61 per cent of the bank customers assigned ratings above the sample average of 3.54 shown in Table 2 . The results confirm the typical $\mathrm{u}$-shaped rating for mobile applications identified by $\mathrm{Fu}$ et al. (2013). The qualitative comments driving these ratings are analysed in the subsequent sections using text mining techniques.

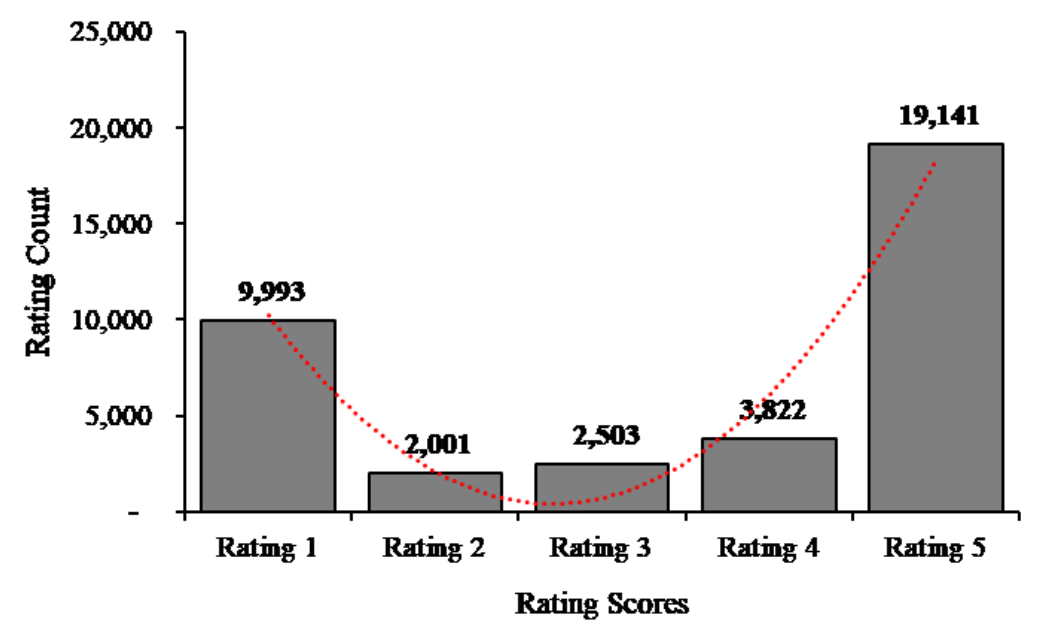

Figure 2: Distribution of user ratings

\subsection{Word Frequency}

Figure 3 shows a plot of the most common terms and their frequencies. The word with the highest frequency is 'good', occurring about 6, 580 times. This is followed by the term 'use', which occurred 4, 018 times. Other top frequent terms include 'can't', 'update', 'work', 'transaction', 'bank', 'try', 'please', 'great', 'nice', 'time' 'login', etc. To a large extent, these terms express sentiments regarding user satisfaction as well as the practical issues encountered while using the apps. The preponderant use of the term 'good' tend to suggest that most users consider the mobile banking apps good enough for the purposes for which they were downloaded. Also, Figure 3 shows that the term 'can't' which occurred 3, 809 times may be indicative of the inability of some users to effectively enjoy certain permissible banking services on their mobile apps. 
Analysing User Experience of Mobile Banking Applications in Nigeria:

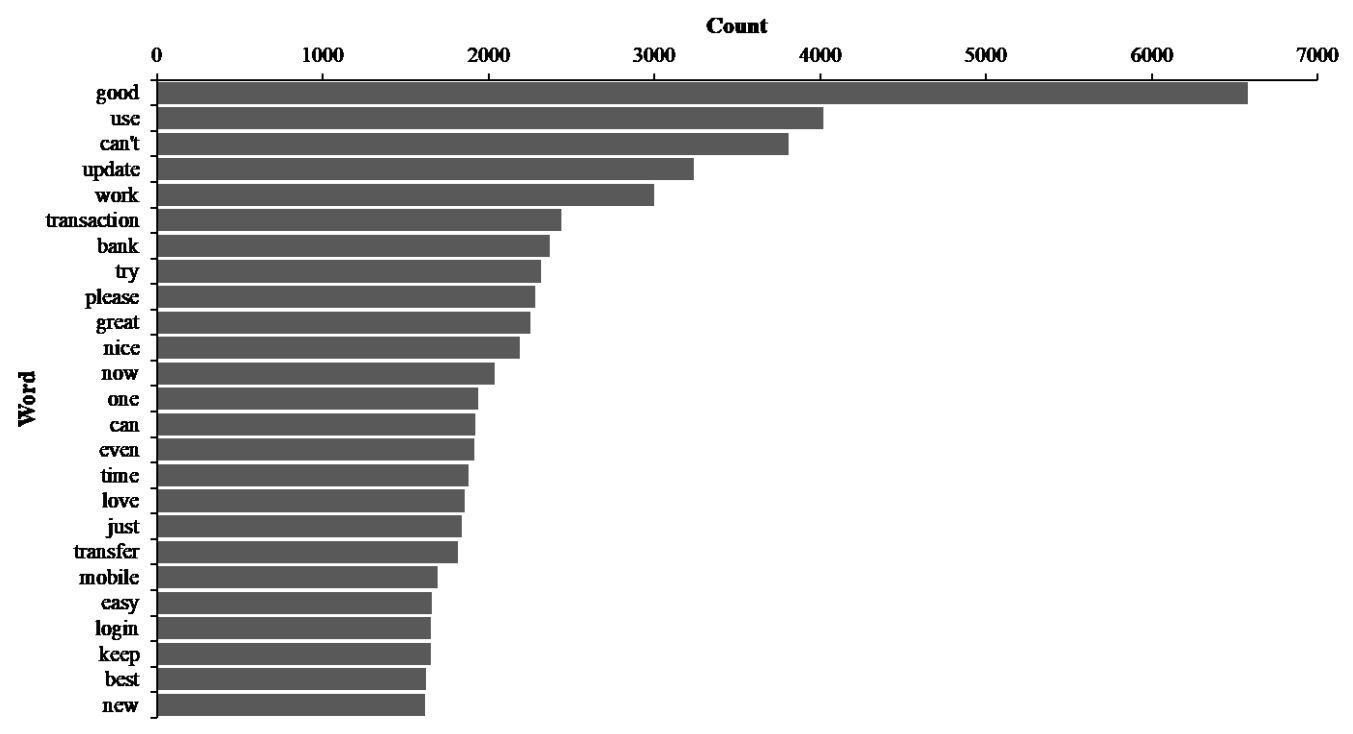

Figure 3: Top 25 frequent terms from full sample

To visualise the content of the reviews, we generate a word cloud shown in Figure 4. The word cloud presents a graphical representation of the most common terms in the corpus of 37, 460 reviews with the more prominent words represented by biggersized fonts. Consistent with the results presented in Figure 3, terms such as 'good', 'use', 'can't', 'update', 'transact', 'download', 'work', feature prominently. On the other hand, terms such as 'data', 'change', 'difficult', 'balance', 'code', 'connect', 'error', 'device', etc are less common.

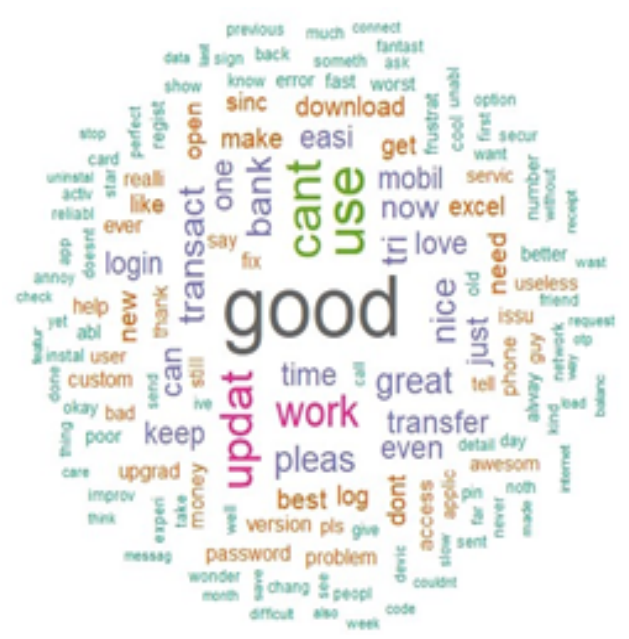

Figure 4: Word cloud from full sample 
It is expected that the hidden topics and sentiments analysed in this study will be driven by the words that are most frequent in the corpus. To identify the words driving the ratings assigned by users, word clouds are generated for the different user ratings as shown in Figure 5. Figure 5a shows that words such as 'can't', 'update', 'work', 'even', 'transact', 'download', 'poor', 'frustrating', 'error', 'log', 'worst', 'bad', 'upgrade', 'don't', etc are dominant in reviews corresponding to a user rating of 1 .

The results for user ratings 1 and 2 are similar, except that words such as 'please', 'make', 'can', 'transact' are more common in the word cloud associated with user rating 2 (Figure 5b). To improve customer satisfaction and contribute to the financial inclusion efforts of the Central Bank of Nigeria, it is important that banks pay attention to user reviews associated with app ratings 1 and 2. Furthermore, results from the word clouds presented in Figures $5 \mathrm{c}$ to $5 \mathrm{e}$ show that reviews corresponding to higher user ratings are dominated by terms associated with positive sentiments. These include terms such as 'good', 'great', 'nice', 'easy', 'excellent', 'love', 'awesome', 'cool', 'work', etc. 
Analysing User Experience of Mobile Banking Applications in Nigeria:

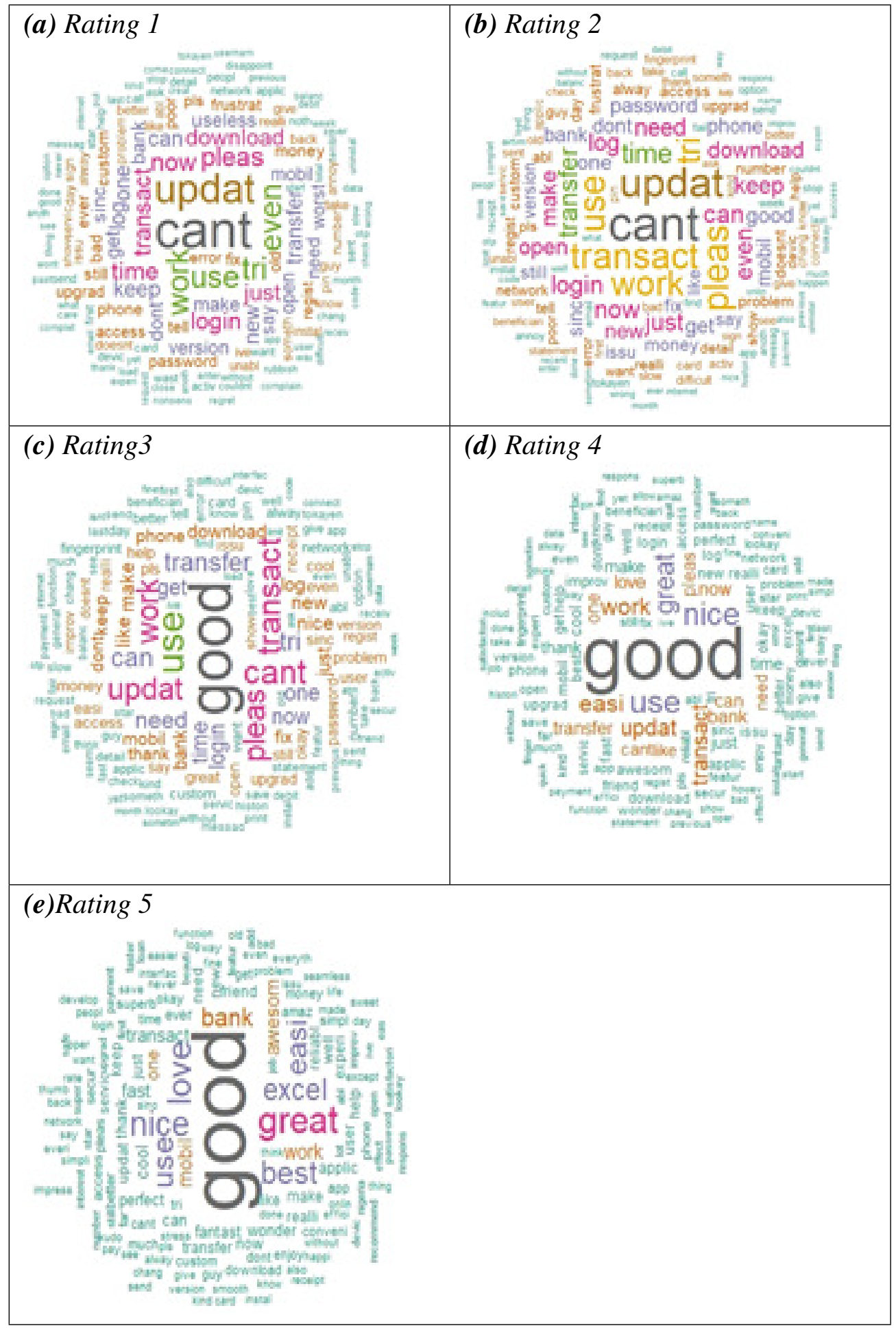

Figure 5: Word cloud by user rating 


\subsection{Analysis of Sentiments}

The results of the sentiments expressed by mobile banking apps users are presented in Table 3. The analysis groups the sentiments into three categories - positive, neutral, and negative; but the study is principally interested in the positive and negative sentiments. Of the 239,568 words analysed, about 17.8 per cent express positive sentiment while only 7.7 per cent express negative sentiment. These results are consistent with our earlier findings regarding the emotions of 'trust', 'anticipation', and ‘joy’ contained in our corpus.

Table 3: Sentiment analysis by bank authorisation category

\begin{tabular}{llcccc}
\hline Sample & Negative & Positive & Neutral & $\begin{array}{l}\text { Total no. } \\
\text { of words }\end{array}$ \\
\hline $\begin{array}{l}\text { Commercial Banks with International Authorisation } \\
\text { (CBIA) }\end{array}$ & $7.9 \%$ & $19.0 \%$ & $73.1 \%$ & 134,364 \\
$\begin{array}{l}\text { Commercial Banks with National Authorisation } \\
\text { (CBNA) }\end{array}$ & $7.4 \%$ & $16.2 \%$ & $76.3 \%$ & 102,594 \\
$\begin{array}{l}\text { Commercial Banks with Regional Authorisation } \\
\text { (CBRA) }\end{array}$ & $6.3 \%$ & $17.1 \%$ & $76.6 \%$ & 732 \\
Non-Interest Banks (NIB) & & & & \\
\hline All & & $7.5 \%$ & $19.3 \%$ & $75.2 \%$ & 1,878 \\
\hline
\end{tabular}

At about 19 per cent each, the reviews associated with mobile banking apps developed by non-interest banks (NIBs) and the commercial banks with international authorisation (CBIA) have the highest share of positive sentiments (Table 3). In other words, the NIB and CBIA recorded shares of positive sentiments that are above the value of 17.8 per cent recorded for the full sample. On the other hand, the mobile banking apps developed by commercial banks with national authorisation (CBNA) attract the least share of positive sentiments of about 16 per cent.The NIBs attracted the least negative sentiments of about 5 per cent.

In Table 4, the list of the top ten positive (42, 655 occurrences) and negative (18, 359 occurrences) sentiment terms contained in our full sample corpus with their frequencies and weights. As shown in Table 4a, the most common positive terms used by mobile banking apps users to describe their experience include: 'good', 'work', 'great', 'love', 'nice', 'new', 'excellent', 'like', and 'thank'. The term 'good' with a 
Analysing User Experience of Mobile Banking Applications in Nigeria: A Text Mining Approach

Omotosho

weight of 0.15 is most dominant of the positive sentiment words.

Table 4: Top ten words with (a) positive sentiments and (b) negative sentiments

\begin{tabular}{llllll}
\hline (a) & & & (b) & & \\
Word & Freq & Weight & Word & Freq & Weight \\
\hline good & 6,578 & 0.154 & please & 2,284 & 0.124 \\
great & 2,253 & 0.053 & bad & 842 & 0.046 \\
nice & 2,190 & 0.051 & useless & 828 & 0.045 \\
love & 1,853 & 0.043 & error & 763 & 0.042 \\
best & 1,620 & 0.038 & worst & 748 & 0.041 \\
new & 1,616 & 0.038 & poor & 720 & 0.039 \\
excellent & 1,372 & 0.032 & annoying & 474 & 0.026 \\
like & 1,213 & 0.028 & slow & 466 & 0.025 \\
thank & 1,098 & 0.026 & never & 433 & 0.024 \\
\hline
\end{tabular}

In contrast, Table $4 \mathrm{~b}$ presents the most frequent negative sentiment words expressed by users to include: 'please', 'problem', 'bad', 'useless', 'worst', 'error', 'poor', 'annoying', 'slow', and 'never'. While some of these terms derive from problems associated with poor information technology infrastructure, quite a number is also associated with poor customer service on the part of the banks. This point is underscored by reviews such as "Just pray not to have cash related issues with this bank. They will ignore you. Wished I never used them". It is therefore important that the banks develop a mechanism for tracking user reviews of their mobile banking apps as much as they attend to in-person complaints received in their various branches.

Table 5: Polarity of reviews by bank authorisation category

\begin{tabular}{lll}
\hline Bank category & $\begin{array}{l}\text { Average } \\
\text { polarity }\end{array}$ & Sd. Polarity \\
\hline All & 0.395 & 0.609 \\
Commercial Banks with International Authorisation (CBIA) & 0.424 & 0.614 \\
Commercial Banks with National Authorisation (CBNA) & 0.345 & 0.598 \\
Commercial Banks with Regional Authorisation (CBRA) & 0.321 & 0.595 \\
Non-Interest Banks (NIB) & 0.474 & 0.564 \\
\hline
\end{tabular}

The average polarity scores and the standard deviation (sd.) for the entire sample as well as the different categories of banks are presented in Table 5. Whereas a negative value of the average sentiment polarity implies a preponderance of negative sentiment terms and a positive value indicates the dominance of positive sentiment terms, 
the absolute value of the polarity score describes the sentiment intensity. The overall average sentiment polarity, which provides a summary measure of the sentiments is 0.395 (Table 5). In line with the results of the average user rating shown in Table 2, the mobile banking apps deployed by NIBs attracted the most positive average polarity score of 0.474 and the least uncertainty measured by the standard deviation regarding the polarity score $(0.564)$. This is followed by the apps deployed by CBIA banks with an average polarity score of 0.424 . However, at 0.614 , the standard deviation associated with the sentiments expressed by users of mobile banking apps deployed by the CBIA is relatively high. The least average polarity score is recorded by CBNA's mobile banking apps. These results highlight the need for banks with low average polarity scores to invest more in their mobile banking platforms if they must remain competitive.

\subsection{Analysis of Emotions}

To further understand the results presented in Section 4.3, the emotions expressed by the bank customers are analysed. The results show a total of 91, 137 emotive words in the corpus. The eight types of emotions allowed for by the NRC dictionary, namely: 'trust', 'anticipation', ‘joy', 'surprise', 'sadness', 'fear', 'anger', and 'disgust' and their respective shares are shown in Figure 6. The three most dominant emotions are 'trust', 'anticipation', and 'joy'. These three categories of emotions are largely positive and they jointly account for about 66 per cent of the total emotions expressed by mobile banking apps users in Nigeria. The 'trust' emotion, which accounts for about 28 per cent, reflects the users' belief in the ability and reliability of their respective mobile banking apps.

The second dominant emotion of 'anticipation' (accounting for 19 per cent) indicates that a substantial number of users expect that the mobile banking apps will continue to deliver the required services. The 'joy' emotion, which accounts for about 18 per cent of the total emotive words implies that approximately 18 times out of 100, users express a feeling of happiness based on their experience with their mobile banking app. The 'surprise' emotion accounts for about 10 per cent of the emotive words detected in the corpus. It is important to note that this category of emotion represents a feeling of unexpectedness or shock, which may either be pleasant or unpleasant. 


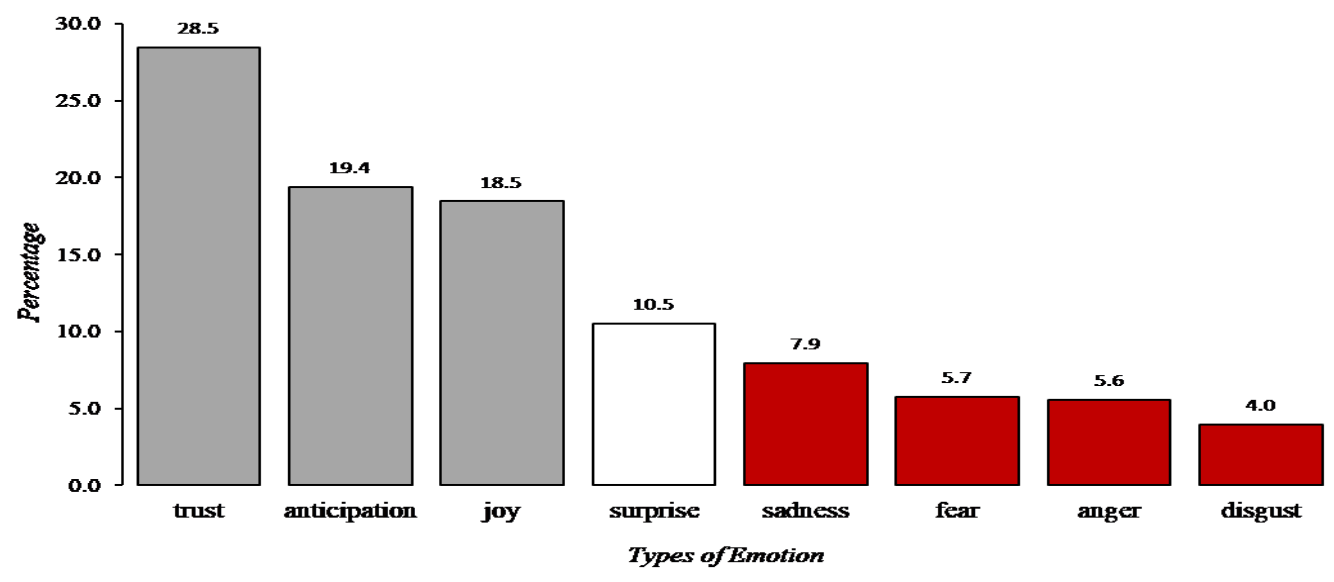

Figure 6: Distribution of emotions from full sample

The less dominant emotions relate to 'sadness', 'fear', 'anger', and 'disgust'. These emotions have a combined share of about $23 \%$ of the emotive words. The terms accounting for these categories of unpleasant emotions include 'bad', 'waste', 'refuses', 'error', 'frustrating', 'annoying', 'ignore', 'never', 'worst', etc. These terms are associated with user complaints regarding either their inability to download the mobile banking apps or the failure of the apps to provide the required services. An example of a review with such unpleasant emotion in the corpus reads as follows: "very bad app. I just wasted my subscription on this app, I tried opening it many times, but it was not functioning well. Don't download please".

\begin{tabular}{lllll}
\multicolumn{5}{l}{ Table 6: Analysis of emotions by bank authorisation (\%) } \\
\hline Emotion type & CBIA & CBNA & CBRA & NIB \\
\hline anger & 5.0 & 6.4 & 3.6 & 2.9 \\
anticipation & 19.4 & 19.3 & 20.2 & 19.3 \\
disgust & 3.9 & 4.2 & 2.7 & 1.6 \\
fear & 5.4 & 6.4 & 3.6 & 4.1 \\
joy & 19.0 & 17.6 & 17.9 & 21.1 \\
sadness & 7.4 & 8.8 & 5.4 & 6.7 \\
surprise & 11.3 & 9.3 & 7.6 & 9.8 \\
trust & 28.6 & 28.1 & 39.0 & 34.5 \\
\hline
\end{tabular}

Furthermore, the emotions generated for the mobile banking apps deployed by the different categories of banks operating in the country were analysed. As shown in 
Table 6, the 'trust' emotion is dominant across the four categories of banks, with regional banks' (CBRA) recording the highest share of about 39 per cent and the national banks (CBNA) having the least (28.1 per cent). For commercial banks with international, national, and regional authorisations, the second dominant emotion is 'anticipation'. Interestingly, the second dominant emotion for non-interest banks (NIB) is 'joy' followed by 'anticipation'. Thus, the 'joy' emotion is highest in the order of NIB, CBIA, CBRA and CBNA.

In terms of the less pleasant emotions expressed by users, the results show that the emotions of 'anger' and 'disgust' are highest under the CBNA category and least under the NIB category. In other words, users of mobile banking apps deployed by the NIBs are least angered and disgusted with their apps. Customers of CBNAs are most 'fearful' of getting the desired services from their mobile banking apps while CBRA customers are least fearful. Similarly, the emotion of 'sadness' is highest under CBNA and least under the CBRA.

\subsection{Topic Analysis}

This section shows the results of the topic model estimated to uncover the hidden topics in the corpus. For ease of interpretation, we heuristically choose five (5) as the number of topics present in the corpus. Based on the most probable terms contained under each topic, labels are assigned to the identified topics. As shown in Table 7, topic 2 has the highest weight in the corpus with a gamma value of 0.302 . The terms occurring under this topic with relatively high probabilities include: 'good', 'use', 'work', 'nice', 'can', etc. Therefore, the study describes topic 2 as capturing user experience with app functionalities. The next dominant is topic 5, with a gamma value of 0.258 and common words that include 'update', 'trying', 'love', 'good', 'nice', 'download' etc. Therefore, a label 'user satisfaction with successful app updates' was intuitively assigned to the topic. 
Analysing User Experience of Mobile Banking Applications in Nigeria:

A Text Mining Approach

Omotosho

Table 7: Identified topics and their weights

\begin{tabular}{|c|c|c|c|c|c|c|c|c|c|c|}
\hline \multirow[t]{2}{*}{$\mathrm{s} / \mathrm{n}$} & \multicolumn{2}{|c|}{1} & \multicolumn{2}{|c|}{$\begin{array}{c}\mathbf{2} \\
\text { Gamma }=0.302\end{array}$} & \multicolumn{2}{|c|}{$\begin{array}{c}\mathbf{3} \\
\text { Gamma }=0.100\end{array}$} & \multicolumn{2}{|c|}{$\begin{array}{c}\mathbf{4} \\
\text { Gamma }=0.120\end{array}$} & \multicolumn{2}{|c|}{$\begin{array}{c}\mathbf{5} \\
\text { Gamma }=0.258\end{array}$} \\
\hline & term & beta & term & beta & term & beta & term & beta & term & beta \\
\hline 1 & bank & 0.0276 & good & 0.0551 & use & 0.0284 & transact & 0.0322 & update & 0.0318 \\
\hline 2 & can't & 0.0242 & use & 0.0295 & can't & 0.0263 & can’t & 0.0308 & try & 0.0203 \\
\hline 3 & work & 0.0234 & work & 0.0169 & good & 0.0174 & update & 0.0210 & love & 0.0184 \\
\hline 4 & even & 0.0187 & nice & 0.0145 & don't & 0.0160 & try & 0.0146 & good & 0.0180 \\
\hline 5 & great & 0.0165 & can & 0.0145 & can & 0.0154 & transfer & 0.0142 & nice & 0.0134 \\
\hline 6 & good & 0.0119 & great & 0.0142 & transfer & 0.0142 & make & 0.0133 & time & 0.0125 \\
\hline 7 & password & 0.0112 & please & 0.0120 & now & 0.0121 & good & 0.0130 & now & 0.0121 \\
\hline 8 & please & 0.0104 & mobile & 0.0109 & make & 0.0114 & new & 0.0124 & $\operatorname{login}$ & 0.0121 \\
\hline 9 & easy & 0.0097 & one & 0.0106 & even & 0.0108 & use & 0.0123 & please & 0.0108 \\
\hline 10 & now & 0.0089 & can’t & 0.0100 & new & 0.0106 & need & 0.0121 & phone & 0.0091 \\
\hline 11 & best & 0.0088 & $\operatorname{login}$ & 0.0089 & keep & 0.0104 & download & 0.0108 & keep & 0.0090 \\
\hline 12 & just & 0.0085 & open & 0.0086 & one & 0.0092 & love & 0.0104 & like & 0.0085 \\
\hline 13 & money & 0.0083 & will & 0.0085 & fix & 0.0090 & one & 0.0094 & download & 0.0084 \\
\hline 14 & new & 0.0083 & transfer & 0.0077 & password & 0.0083 & just & 0.0083 & use & 0.0084 \\
\hline 15 & need & 0.0083 & transact & 0.0072 & phone & 0.0075 & phone & 0.0079 & since & 0.0084 \\
\hline 16 & excellent & 0.0080 & easy & 0.0072 & try & 0.0074 & keep & 0.0075 & one & 0.0083 \\
\hline 17 & $\operatorname{login}$ & 0.0078 & still & 0.0071 & download & 0.0074 & time & 0.0072 & just & 0.0082 \\
\hline 18 & application & 0.0075 & get & 0.0071 & time & 0.0073 & easy & 0.0072 & excellent & 0.0078 \\
\hline 19 & will & 0.0073 & bank & 0.0070 & bank & 0.0071 & useless & 0.0066 & transaction & 0.0077 \\
\hline 20 & keep & 0.0067 & just & 0.0070 & applicatio & 10.0068 & fix & 0.0066 & best & 0.0073 \\
\hline $\begin{array}{l}\text { Assigned } \\
\text { topic }\end{array}$ & $\begin{array}{l}\text { Feedback or } \\
\text { responsivene } \\
\text { observations }\end{array}$ & $\begin{array}{l}\text { banks' } \\
\text { to user }\end{array}$ & $\begin{array}{l}\text { User } \\
\text { ence wi } \\
\text { function }\end{array}$ & $\begin{array}{l}\text { experi- } \\
\text { th app } \\
\text { alities }\end{array}$ & $\begin{array}{l}\text { Operation } \\
\text { ures as } \\
\text { with the a }\end{array}$ & $\begin{array}{l}\text { al fail- } \\
\text { sociated } \\
\text { pps }\end{array}$ & $\begin{array}{l}\text { Challenges } \\
\text { users with } \\
\text { grades }\end{array}$ & $\begin{array}{l}\text { faced by } \\
\text { app up- }\end{array}$ & $\begin{array}{l}\text { User sat } \\
\text { with succes } \\
\text { upgrades }\end{array}$ & $\begin{array}{l}\text { isfaction } \\
\text { sful app }\end{array}$ \\
\hline
\end{tabular}

The third dominant topic (topic 1) features terms such as 'bank', 'can't', 'work', 'even', 'great', 'good', 'password' and has a gamma value of 0.220. Consequently, a label that describes the responsiveness of the banks to issues arising from the use of their apps was assigned. The last two topics relate to the challenges faced by users in the process of installing updated version of their mobile banking apps (topic 4, gamma $=0.120$ ) and the operational failures associated with the mobile banking apps (topic 3, gamma $=0.100$ ). These results imply that conversations relating to the satisfaction derived from using mobile banking apps were more dominant, compared to the issues relating to the logistics of using the apps and their updates.

\subsection{Conclusion and Policy Recommendations}

This paper analyses reviews written by users of mobile banking apps in Nigeria to derive useful insights regarding the sentiments and emotions expressed by the users. The textual data comprises 37, 460 reviews mined from iOS- and Android-based mobile banking apps deployed by twenty-two banks operating in Nigeria. The study 
argues that beyond operational benefits, an analysis of the feedback provided by users of mobile banking apps is useful for a number of reasons, including the enhancement of payments system stability as well as the promotion of financial inclusion.

The study documents a number of interesting results. First, most of the users of mobile banking apps are quite satisfied with their mobile banking experience based on the average rating assigned to the apps. About 51 per cent of the users assigned the highest ranking of 5 while only about 27 per cent assigned the least ranking of 1. The average ratings for the mobile apps deployed by non-interest banks and the banks with international authorisation are above the industry average while the apps for banks with national authorisation record the least average rating. Second, the most frequent term contained in the corpus is 'good' indicating that a preponderance of users adjudged their apps functional enough for their mobile banking requirements. Third, reviews associated low ratings (app ratings 1 and 2) are dominated by words such as 'can't', 'update', 'transaction', 'work', 'please', 'download', 'use', and 'transfer'. It is important that banks whose apps account for a greater share of the low ratings pay attention to challenges relating to apps updates, failed transactions, and other unpleasant experiences documented in the user reviews.

Fourth, the corpus is dominated by positive sentiments with the demonstrated emotions ranging from 'trust' to 'joy'. The corpus for non-interest banks recorded the highest share of positive sentiments, followed by banks with international authorisation. The most frequent words driving the positive sentiments expressed by the users include 'good', 'work', 'great', 'nice', 'love', 'best', 'new', and 'excellent', among others. Lastly, the results show that the topics in the corpus can be captured under 4 main themes, which relate to: the description of user experience with app functionalities, feedback on banks' responsiveness to user observations, operational failures associated with the mobile banking apps, and the issues relating to app updates. We recommend for banks to continue to educate users on the existing functionalities of their apps while also ensuring that they respond to user complaints promptly and effectively. It is hoped that future research efforts would throw more light on the issues identified in this paper by (i) studying the evolution of user sentiments over time in a manner that accounts for the rapidly changing technological landscape in the fi- 
Analysing User Experience of Mobile Banking Applications in Nigeria:

A Text Mining Approach

Omotosho

nancial industry, and (ii) utilising primary data obtained from a structured survey to further analyse user satisfaction under a setting that allows for parametric analysis.

\section{References}

Adewoye, J. O. (2013). Impact of mobile banking on service delivery in the Nigerian commercial banks. International Review of Management and Business Research, 2(2), 333-344.

Aggarwal, S., Brailovskaya, V., \& Robinson, J. (2020). Cashing in (and out): Experimental evidence on the effects of mobile money in Malawi. AEA Papers and Proceedings, $110,599-604$.

Agwu, P. E., \& Carter, A. L. (2014). Mobile phone banking in Nigeria: Benefits, problems and prospects. International Journal of Business and Commerce, 3(6), 50-70.

Aron, J. (2018). Mobile money and the economy: A review of the evidence. The World Bank Research Observer, 33(2), 135-188.

Bankole, F. O., Bankole, O. O., \& Brown, I. (2011). Mobile banking adoption in Nigeria. The Electronic Journal of Information Systems in Developing Countries, 47(1), $1-23$.

Barnes, S. J., \& Corbitt, B. (2003). Mobile banking: Concept and potential. International journal of mobile communications, 1(3), 273-288

Bongomin, G. O. C., Ntayi, J. M., Munene, J. C., \& Malinga, C. A. (2018). Mobile money and financial inclusion in Sub-Saharan Africa: The moderating role of social networks. Journal of African Business, 19(3), 361-384.

Blei, D. M., \& Lafferty, J. D. (2009). Topic models. In Srivastava, A. \& Sahami, M. (Eds), Text mining: classification, clustering, and applications, Chapman \& Hall/CRC Press, 71-89.

Blei, D. M., Ng, A. Y., \& Jordan, M. I. (2003). Latent Dirichlet allocation. Journal of machine Learning research, 3, 993-1022.

Bose, S., Saha, U., Kar, D., Goswami, S., Nayak, A. K., \& Chakrabarti, S. (2017). RSentiment: A tool to extract meaningful insights from textual reviews. In Proceedings of the 5th International Conference on Frontiers in Intelligent Computing: Theory and Applications, 259-268. 
Calvo-González, O., Eizmendi, A., \& Reyes, G. J. (2018). Winners never quit, Quitters never grow: Using text mining to measure policy volatility and its link with long-term growth in Latin America. World Bank Policy Research Working Paper (8310).

Castle, S., Pervaiz, F., Weld, G., Roesner, F., \& Anderson, R. (2016). Let's talk money: Evaluating the security challenges of mobile money in the developing world. In Proceedings of the 7th Annual Symposium on Computing for Development, 1-10.

Chang, J., \& Dai, A. (2015). 'Package-lda': Collapsed Gibbs sampling methods for topic models. CRAN Repository. Retrieved from: https://cran. r-project. org/package= lda.

Chang, J., Boyd-Graber, J., Wang, C., Gerrish, S., \& Blei, D. M. (2009, December). Reading tea leaves: How humans interpret topic models. In Neural information processing systems, 22, 288-296.

Chatain, P. L., Zerzan, A., Noor, W., Dannaoui, N., \& De Koker, L. (2011). Protecting mobile money against financial crimes: Global policy challenges and solutions. The World Bank.

Committee on Payment and Settlement Systems (2012). Principles for Financial Market Infrastructures, Bank for International Settlements.

Contini, D., Crowe, M., Merritt, C., Oliver, R., \& Mott, S. (2011). Mobile payments in the United States: Mapping out the road ahead. Federal Reserve Bank of Atlanta and Federal Reserve Bank of Boston White Paper.

Debortoli, S., Müller, O., Junglas, I., \& vom Brocke, J. (2016). Text mining for information systems researchers: An annotated topic modelling tutorial. Communications of the Association for Information Systems, 39(1), 7.

Deerwester, S., Dumais, S. T., Furnas, G. W., Landauer, T. K., \& Harshman, R. (1990). Indexing by latent semantic analysis. Journal of the American society for information science, 41(6), 391-407.

Dittus, P. \& Klein, M. (2011). On harnessing the potential of financial inclusion", BIS Working Paper, No. 347.

Feinerer, K. H. \& Meyer, D. (2008). Text mining infrastructure in R. Journal of Statistical Software, 25(5), 1-54.

Fu, B., Lin, J., Li, L., Faloutsos, C., Hong, J., \& Sadeh, N. (2013). Why people hate your App: Making sense of user feedback in a mobile App store. In Proceedings of 
Analysing User Experience of Mobile Banking Applications in Nigeria:

A Text Mining Approach

Omotosho

the 19th ACM SIGKDD international conference on Knowledge discovery and data mining, 1276-1284.

G20 Financial Inclusion Experts Group. (2010). Innovative financial inclusion: principles and report on innovative financial inclusion from the access through innovation subgroup of the G20 Financial Inclusion Experts Group.

Global System for Mobile Communication Association (2019). State of the industry report on mobile money.

https://www.gsma.com/mobilefordevelopment/wp-content/uploads/2019/07/GSMA-Stateof-Mobile-Internet-Connectivity-Report-2019.pdf

Hansen, S., McMahon, M., \& Prat, A. (2018). Transparency and deliberation within the FOMC: a computational linguistics approach. The Quarterly Journal of Economics, 133(2), 801-870

Ifeonu, R. O., \& Ward, R. (2015). The impact of technology trust on the acceptance of mobile banking technology within Nigeria. IEEE African Journal of Computing \& ICTs, 8(4).

Jack, W., \& Suri, T. (2011). Mobile money: The economics of M-PESA. National Bureau of Economic Research (No. w16721).

Khan, H. U., \& Ejike, A. C. (2017). An assessment of the impact of mobile banking on traditional banking in Nigeria. International Journal of Business Excellence, 11(4), 446-463.

Khiaonarong, T. (2014). Oversight issues in mobile payments. Working paper 14-123, International Monetary Fund, Washington, DC, July.

Kwartler, T. (2017). Text mining in practice with $R$. John Wiley \& Sons.

Mbiti, I., \& Weil, D. N. (2015). Mobile banking: The impact of M-Pesa in Kenya. African Successes, Volume III: Modernization and Development, University of Chicago Press, 247-293.

Mohammad, S. \& Turney, P. (2010). Emotions evoked by common words and phrases: Using mechanical turk to create an emotion lexicon. Proceedings of the NAACL HLT 2010 workshop on computational approaches to analysis and generation of emotion in text, 26-34. 
Odumeru, J. A. (2013). Going cashless: Adoption of mobile banking in Nigeria. Arabian Journal of Business and Management Review, 62(1085), 1-9.

Okon, A. N., \& Amaegberi, M. A. (2018). Mobile banking transactions and bank profitability in Nigeria. International Journal of Economics, Commerce and Management, 6(6), 692-716.

Olaleye, S. A., Sanusi, I. T., \& Oyelere, S. S. (2017). Users experience of mobile money in Nigeria. In 2017 IEEE AFRICON, IEEE, 929-934.

Omotosho, B. S. (2020). Central bank communication in Ghana: Insights from a text mining analysis. Noble International Journal of Economics and Financial Research, 5(1), $1-13$

Ozili, P. K. (2018). Impact of digital finance on financial inclusion and stability. Borsa Istanbul Review, 18(4), 329-340.

Patnam, M., \& Yao, W. (2020). The real effects of mobile money: Evidence from a largescale fintech expansion. IMF working paper WP/20/138.

Reaves, B., Bowers, J., Scaife, N., Bates, A., Bhartiya, A., Traynor, P., \& Butler, K. R. (2017). Mobile money, Mobile problems: Analysis of branchless banking applications. ACM Transactions on Privacy and Security (TOPS), 20(3), 1-31.

Shirota, Y., Hashimoto, T., \& Sakura, T. (2015, July). Topic extraction analysis for monetary policy minutes of Japan in 2014. In Industrial Conference on Data Mining (pp. 141-152). Springer, Cham.

Total System Services (2018). TSYS U.S. Consumer Payment Study Report. Retrieved from https://www.tsys.com/Assets/TSYS/downloads/rs_2018-us-consumer-payment-study.pdf.

Tumala, M. M., \& Omotosho, B. S. (2019). A text mining analysis of central bank monetary policy communication in Nigeria. CBN Journal of Applied Statistics, 10(2), 73-107.

Wieser, C., Bruhn, M., Kinzinger, J., Ruckteschler, C., \& Heitmann, S. (2019). The impact of mobile money on poor rural households: Experimental evidence from Uganda. The World Bank Policy Research Working Paper, No. 8913. 
Analysing User Experience of Mobile Banking Applications in Nigeria:

Appendix 1: Summary of selected studies

\begin{tabular}{|c|c|c|c|}
\hline Author & $\begin{array}{l}\text { Literature } \\
\text { strand }\end{array}$ & $\begin{array}{l}\text { Method } \\
\text { Analysis }\end{array}$ & Key findings \\
\hline $\begin{array}{l}\text { Bankole et al. } \\
\text { (2011) }\end{array}$ & $\begin{array}{l}\text { Determinants } \\
\text { of mobile } \\
\text { banking } \\
\text { adoption }\end{array}$ & $\begin{array}{l}\text { Regression } \\
\text { analysis of } \\
\text { survey data }\end{array}$ & $\begin{array}{l}\text { Based on a survey of } 231 \text { users, } \\
\text { study identified culture as an im- } \\
\text { portant factor in the usage and } \\
\text { adoption of mobile banking in } \\
\text { Nigeria. }\end{array}$ \\
\hline Odumeru (2013) & $\begin{array}{l}\text { Determinants } \\
\text { of mobile } \\
\text { banking } \\
\text { adoption }\end{array}$ & $\begin{array}{l}\text { Regression } \\
\text { analysis applied } \\
\text { to primary data }\end{array}$ & $\begin{array}{l}\text { Factors that determine mobile } \\
\text { banking usage in Nigeria include } \\
\text { its relative advantage over other } \\
\text { solutions, complexity of the sys- } \\
\text { tem, compatibility with the cir- } \\
\text { cumstances of the user, and the } \\
\text { visibility of its benefits. }\end{array}$ \\
\hline $\begin{array}{l}\text { Agwu and Carter } \\
(2014)\end{array}$ & $\begin{array}{l}\text { Determinants } \\
\text { of mobile } \\
\text { banking } \\
\text { adoption }\end{array}$ & $\begin{array}{l}\text { Thematic anal- } \\
\text { ysis of survey } \\
\text { data }\end{array}$ & $\begin{array}{l}\text { Based on focus group dis- } \\
\text { cussions and interviews, study } \\
\text { showed that adoption of mobile } \\
\text { banking in Nigeria is a function } \\
\text { of by customers' level of aware- } \\
\text { ness, convenience of use, se- } \\
\text { curity, cost of transaction com- } \\
\text { pared to other alternatives. }\end{array}$ \\
\hline $\begin{array}{l}\text { Ifeonu and Ward } \\
(2015)\end{array}$ & $\begin{array}{l}\text { Determinants } \\
\text { of mobile } \\
\text { banking } \\
\text { adoption }\end{array}$ & $\begin{array}{l}\text { Technology ac- } \\
\text { ceptance model } \\
\text { applied to pri- } \\
\text { mary data }\end{array}$ & $\begin{array}{l}\text { Trust is key to the adoption of } \\
\text { mobile banking. Confidentiality, } \\
\text { integrity, authentication, access } \\
\text { control, and best business prac- } \\
\text { tices matter for mobile technol- } \\
\text { ogy trust in Nigeria. }\end{array}$ \\
\hline $\begin{array}{l}\text { Khan and Ejike } \\
\text { (2017) }\end{array}$ & $\begin{array}{l}\text { Determinants } \\
\text { of mobile } \\
\text { banking } \\
\text { adoption }\end{array}$ & $\begin{array}{l}\text { Logistic regres- } \\
\text { sion applied to } \\
\text { survey data }\end{array}$ & $\begin{array}{l}\text { Based on a survey of } 400 \text { people } \\
\text { in Nigeria, study found that mo- } \\
\text { bile banking adoption is deter- } \\
\text { mined by people's literacy level, } \\
\text { versatility of the system, and } \\
\text { convenience of use. }\end{array}$ \\
\hline
\end{tabular}


Appendix 1 contd.: Summary of selected studies

\begin{tabular}{|c|c|c|c|}
\hline Author & $\begin{array}{l}\text { Literature } \\
\text { strand }\end{array}$ & $\begin{array}{l}\text { Method of } \\
\text { Analysis }\end{array}$ & Key findings \\
\hline $\begin{array}{l}\text { Contini et al. } \\
(2011)\end{array}$ & $\begin{array}{l}\text { Regulatory } \\
\text { oversight and } \\
\text { security issues } \\
\text { in mobile } \\
\text { banking and } \\
\text { payments }\end{array}$ & $\begin{array}{l}\text { Review of liter- } \\
\text { ature }\end{array}$ & $\begin{array}{l}\text { The development of an ap- } \\
\text { propriate regulatory oversight } \\
\text { model by both bank and non- } \\
\text { bank regulators is key for } \\
\text { a successful mobile payment } \\
\text { system. Such joint efforts are } \\
\text { also helpful in clarifying com- } \\
\text { pliance responsibilities. }\end{array}$ \\
\hline $\begin{array}{l}\text { Chatain et al. } \\
\text { (2011) }\end{array}$ & $\begin{array}{l}\text { Regulatory } \\
\text { oversight and } \\
\text { security issues } \\
\text { in mobile } \\
\text { banking and } \\
\text { payments }\end{array}$ & $\begin{array}{l}\text { Review of liter- } \\
\text { ature }\end{array}$ & $\begin{array}{l}\text { Countries must ensure an en- } \\
\text { abling AML/CFT legal and } \\
\text { regulatory framework that is } \\
\text { comprehensive, sound, clear, } \\
\text { non-discriminatory, and pro- } \\
\text { portionate. Policy makers are } \\
\text { to also promote frameworks } \\
\text { that balance financial inclu- } \\
\text { sion objectives with financial } \\
\text { integrity and encourage inter- } \\
\text { agency coordination. }\end{array}$ \\
\hline $\begin{array}{l}\text { Khiaonarong } \\
\text { (2014) }\end{array}$ & $\begin{array}{l}\text { Regulatory } \\
\text { oversight and } \\
\text { security issues } \\
\text { in mobile } \\
\text { banking and } \\
\text { payments }\end{array}$ & $\begin{array}{l}\text { Review of inter- } \\
\text { national experi- } \\
\text { ence }\end{array}$ & $\begin{array}{l}\text { To preserve public confidence } \\
\text { in mobile payments system } \\
\text { and enhance financial stabil- } \\
\text { ity, financial authorities should } \\
\text { implement oversight measures } \\
\text { such as: an explicit legal } \\
\text { regime; anti-money launder- } \\
\text { ing \& countering the financ- } \\
\text { ing of terrorism measures for } \\
\text { preventing financial integrity } \\
\text { risks without stifling innova- } \\
\text { tion; fund protection mea- } \\
\text { sures such as pass through de- } \\
\text { posit insurance; contingency } \\
\text { plans for operational disrup- } \\
\text { tions; and risk controls in pay- } \\
\text { ment systems. }\end{array}$ \\
\hline
\end{tabular}


Analysing User Experience of Mobile Banking Applications in Nigeria:

Appendix 1 contd.: Summary of selected studies

\begin{tabular}{|c|c|c|c|}
\hline $\begin{array}{l}\text { Castle et al. } \\
(2016)\end{array}$ & $\begin{array}{l}\text { Regulatory } \\
\text { oversight and } \\
\text { security issues } \\
\text { in mobile } \\
\text { banking and } \\
\text { payments }\end{array}$ & $\begin{array}{l}\text { Systemic threat } \\
\text { model }\end{array}$ & $\begin{array}{l}\text { Security vulnerabilities in dig- } \\
\text { ital financial ecosystem is not } \\
\text { as bad as it is often por- } \\
\text { trayed. While evidence of at- } \\
\text { tack vectors is found in sev- } \\
\text { eral mobile banking apps, ser- } \\
\text { vice providers are generally } \\
\text { aware of the threats and mak- } \\
\text { ing "security-conscious deci- } \\
\text { sions". }\end{array}$ \\
\hline $\begin{array}{l}\text { Reaves et al. } \\
(2017)\end{array}$ & $\begin{array}{l}\text { Regulatory } \\
\text { oversight and } \\
\text { security issues } \\
\text { in mobile } \\
\text { banking and } \\
\text { payments }\end{array}$ & $\begin{array}{l}\text { Automated } \\
\text { analysis }\end{array}$ & $\begin{array}{l}\text { Based on an evaluation of the } \\
\text { security features of selected } \\
\text { mobile money services appli- } \\
\text { cations, it was shown that sig- } \\
\text { nificant vulnerabilities exist. } \\
\text { It argued that substantial im- } \\
\text { provements are required to en- } \\
\text { sure that app users and their } \\
\text { funds are protected. }\end{array}$ \\
\hline $\begin{array}{l}\text { Jack and Suri } \\
(2011)\end{array}$ & $\begin{array}{l}\text { Economic } \\
\text { impacts of } \\
\text { mobile bank- } \\
\text { ing services }\end{array}$ & $\begin{array}{l}\text { Analysis of sur- } \\
\text { vey data }\end{array}$ & $\begin{array}{l}\text { Mobile money helps in facili- } \\
\text { tating trade, increasing house- } \\
\text { hold savings, improving re- } \\
\text { source allocation, and promot- } \\
\text { ing informal risk-sharing in } \\
\text { Kenya. }\end{array}$ \\
\hline Adewoye (2013) & $\begin{array}{l}\text { Economic } \\
\text { impacts of } \\
\text { mobile bank- } \\
\text { ing services }\end{array}$ & $\begin{array}{l}\text { Non-parametric } \\
\text { statistical tests } \\
\text { applied to } \\
\text { primary data }\end{array}$ & $\begin{array}{l}\text { The introduction of mobile } \\
\text { banking helps Nigerian banks } \\
\text { to improve the quality of ser- } \\
\text { vice offered to their customers; } \\
\text { thus, leading to higher cus- } \\
\text { tomer satisfaction. }\end{array}$ \\
\hline
\end{tabular}


Appendix 1 contd.: Summary of selected studies

\begin{tabular}{|c|c|c|c|}
\hline $\begin{array}{l}\text { Mbiti and Weil } \\
(2015)\end{array}$ & $\begin{array}{l}\text { Economic } \\
\text { impacts of } \\
\text { mobile bank- } \\
\text { ing services }\end{array}$ & $\begin{array}{l}\text { Fixed effect in- } \\
\text { strumental vari- } \\
\text { able regression }\end{array}$ & $\begin{array}{l}\text { Mobile money (M-Pesa) re- } \\
\text { duces the cost of money trans- } \\
\text { fers in Kenya, generates ver- } \\
\text { tical integration benefits, in- } \\
\text { creases the efficiency of the } \\
\text { banking system, broadens fi- } \\
\text { nancial inclusion, and leads to } \\
\text { increase in bank use, savings } \\
\text { and employment. }\end{array}$ \\
\hline $\begin{array}{l}\text { Okon and } \\
\text { Amaegberi } \\
(2018)\end{array}$ & $\begin{array}{l}\text { Economic } \\
\text { impacts of } \\
\text { mobile bank- } \\
\text { ing services }\end{array}$ & Panel analysis & $\begin{array}{l}\text { Mobile banking and other } \\
\text { electronic payment channels } \\
\text { boost bank's profitability in } \\
\text { Nigeria. }\end{array}$ \\
\hline Ozili (2018) & $\begin{array}{l}\text { Economic } \\
\text { impacts of } \\
\text { mobile bank- } \\
\text { ing services }\end{array}$ & $\begin{array}{l}\text { Review of liter- } \\
\text { ature }\end{array}$ & $\begin{array}{l}\text { Digital finance impacts pos- } \\
\text { itively on financial inclusion } \\
\text { and financial stability. The } \\
\text { convenience associated with } \\
\text { the use of digital finance is par- } \\
\text { ticularly of benefit to individ- } \\
\text { uals with low and variable in- } \\
\text { come. }\end{array}$ \\
\hline Aron (2018) & $\begin{array}{l}\text { Economic } \\
\text { impacts of } \\
\text { mobile bank- } \\
\text { ing services }\end{array}$ & $\begin{array}{l}\text { Empirical liter- } \\
\text { ature review }\end{array}$ & $\begin{array}{l}\text { Mobile money promotes finan- } \\
\text { cial inclusion and fosters risk- } \\
\text { sharing in the informal sector } \\
\text { through the reduction in trans- } \\
\text { action costs of domestic trans- } \\
\text { fers. }\end{array}$ \\
\hline $\begin{array}{l}\text { Bongomin et al. } \\
\text { (2018) }\end{array}$ & $\begin{array}{l}\text { Economic } \\
\text { impacts of } \\
\text { mobile bank- } \\
\text { ing services }\end{array}$ & $\begin{array}{l}\text { Graphical } \\
\text { method }\end{array}$ & $\begin{array}{l}\text { Mobile money as well as the } \\
\text { existence of social networks } \\
\text { among users promote financial } \\
\text { inclusion in rural Uganda }\end{array}$ \\
\hline $\begin{array}{l}\text { Wieser et al. } \\
\text { (2019) }\end{array}$ & $\begin{array}{l}\text { Economic } \\
\text { impacts of } \\
\text { mobile bank- } \\
\text { ing services }\end{array}$ & $\begin{array}{l}\text { Intention to } \\
\text { treat model } \\
\text { using panel data }\end{array}$ & $\begin{array}{l}\text { Mobile money improves liveli- } \\
\text { hoods in poor and remote } \\
\text { settings of Uganda. It in- } \\
\text { creases self- employment, re- } \\
\text { duces food insecurity, and re- } \\
\text { duces the cost of remittance } \\
\text { transactions. }\end{array}$ \\
\hline
\end{tabular}


Analysing User Experience of Mobile Banking Applications in Nigeria:

Appendix 1 contd.: Summary of selected studies

\begin{tabular}{|c|c|c|c|}
\hline $\begin{array}{l}\text { Patnam and Yao } \\
(2020)\end{array}$ & $\begin{array}{l}\text { Economic } \\
\text { impacts of } \\
\text { mobile bank- } \\
\text { ing services }\end{array}$ & $\begin{array}{l}\text { Regression } \\
\text { discontinuity } \\
\text { design }\end{array}$ & $\begin{array}{l}\text { Use of mobile money ser- } \\
\text { vices improves the resilience } \\
\text { of households to shocks, helps } \\
\text { firms improve their sales, and } \\
\text { creates greater future sales op- } \\
\text { timism amongst firms in India. }\end{array}$ \\
\hline $\begin{array}{l}\text { Aggarwal et al. } \\
(2020)\end{array}$ & $\begin{array}{l}\text { Economic } \\
\text { impacts of } \\
\text { mobile bank- } \\
\text { ing services }\end{array}$ & $\begin{array}{l}\text { Randomised } \\
\text { control trial }\end{array}$ & $\begin{array}{l}\text { The use of mobile money } \\
\text { services facilitates savings } \\
\text { amongst individuals and } \\
\text { microentrepreneurs in Malawi }\end{array}$ \\
\hline $\begin{array}{l}\text { Olaleye et } \begin{array}{l}\text { al. } \\
(2017)\end{array} \\
\end{array}$ & $\begin{array}{l}\text { Analysis of } \\
\text { user experi- } \\
\text { ence }\end{array}$ & $\begin{array}{l}\text { Partial least } \\
\text { squares applied } \\
\text { to primary data }\end{array}$ & $\begin{array}{l}\text { Dimensions such as privacy, } \\
\text { security and convenience con- } \\
\text { tribute positively to the expe- } \\
\text { rience of users while anxieties } \\
\text { relating to the use of mobile } \\
\text { apps contributes negatively. }\end{array}$ \\
\hline
\end{tabular}

